\title{
Evaluation of Andira inermis stem bark extract for hypoglycaemic and antioxidant effects'
}

Maxwell Osaronowen Egua ${ }^{{ }^{*}}$ (D) Florence Chimezie Nwinyi ${ }^{2}$, Ode Julius Okwoche ${ }^{2}$, Onakpa Micheal Monday ${ }^{2}$, Akande Motunrayo Ganiyat ${ }^{2}$, Onoja Samuel Okwudili ${ }^{3}$, Mikail Hudu Garba², Akumka David Dezi ${ }^{2}$ and Adamu Mohammed ${ }^{2}$

\begin{abstract}
Background: The aqueous methanolic extract of Andira inermis(A. inermis) stem bark was screened for phytochemical constituents, antioxidant activity, acute oral toxicity, and preliminary prophylactic normoglycaemic test and effect on Oral Glucose Tolerance in albino rats.

Methods: Andira inermis was double macerated and extracted with $80 \%$ methanol. Phytochemical analysis and acute toxicity were performed using standard methods. The extract was screened for in vitro antioxidant activity using Ferric Reducing/Antioxidant Power (FRAP) and 2,2-diphenyl-1-picrylhydrazyl (DPPH) free radical scavenging spectrophotometric assays. Prophylactic control of glucose was evaluated in normoglycaemic and glucosechallenged albino rats. Graded test doses (100-400 mg/kg body weight) of the extract were used in the investigation. The effects observed were compared with that of glibenclamide $(0.2 \mathrm{mg} / \mathrm{kg})$ and distilled water control groups.
\end{abstract}

Results: The stem bark extract of $A$. inermis was found to contain saponins, terpenes, tannins, steroids, flavanoids, anthraquinones, carbohydrates and alkaloids. The extract was found to have a significant in vitro antioxidant activity in both methods. The oral acute toxicity study showed the extract had $L_{50}$ greater than $5000 \mathrm{mg} / \mathrm{kg}$. The extract significantly $(p \leq 0.05)$ reduced blood glucose levels in normoglycaemic animal model (the control group seen to have $-5.6(-8.7 \%)$ poor glucose handling; and the glibenclamide\& extract treatment group $(100 \mathrm{mg} / \mathrm{kg})$ to positively reduce blood glucose $14.8(26.8 \%) \& 16.4(25.9 \%)$ respectively). The glucose challenged test, from the $1 \mathrm{st}$ hour, showed $-57.4(-89.4 \%),-26.8(-33.8 \%),-23.8(-26.3 \%),-12.8(-13.9 \%)$ and $-9.8(-10.4 \%)$ for the vehicle control, glibenclamide (positive control), and the 100, $200 \& 400 \mathrm{mg} / \mathrm{kg}$ extract treatment groups respectively. The extract showed mild hypoglycemic effect in the results recorded, up to the 4th hour.

Conclusion: The results of this study elucidated that the aqueous methanolic extract of Andira inermis stem bark possessed potent antioxidant phyto-constituents with potential hypoglycaemic effects that could be explored for therapeutic use worldwide following isolation and characterization of the bioactive principles. And the results also authenticate the folklore use of the plant.

Keywords: Antioxidant, Extract, Phytochemical, Glucose, Control

\footnotetext{
* Correspondence: egua.osaronowen@uniabuja.edu.ng

'Department of Pharmacology and Therapeutics, College of Health Sciences,

University of Abuja, Abuja, Nigeria

Full list of author information is available at the end of the article
}

\section{Springer Open}

(c) The Author(s). 2020 Open Access This article is licensed under a Creative Commons Attribution 4.0 International License, which permits use, sharing, adaptation, distribution and reproduction in any medium or format, as long as you give appropriate credit to the original author(s) and the source, provide a link to the Creative Commons licence, and indicate if changes were made. The images or other third party material in this article are included in the article's Creative Commons licence, unless indicated otherwise in a credit line to the material. If material is not included in the article's Creative Commons licence and your intended use is not permitted by statutory regulation or exceeds the permitted use, you will need to obtain permission directly from the copyright holder. To view a copy of this licence, visit http://creativecommons.org/licenses/by/4.0/. 


\section{Introduction}

The World Health Organisation (WHO) reported that diabetic mellitus (DM) is fast becoming a pandemic [1]. Diabetes is projected to be one of the world's main disablers and killers; therefore immediate action is needed to stem the tide of diabetes and to introduce cost-effective treatment strategies to reverse this trend [2]. Approximately 220 million people will be affected with diabetes in the year 2020 [3]. WHO estimates the number of people with diabetes, world-wide, will increase to at least 300 million by 2025 . The number of deaths attributed to diabetes is likely to be around 4 million deaths per year which is about $9 \%$ of the global total [2]. Diabetes mellitus is a serious endocrine syndrome of multiple disorders with different aetiologies, characterized by derangement of carbohydrate, protein, and fat metabolism caused by a complete or relative insufficiency in insulin secretion and/ or insulin action [4] with the central feature being hyperglycemia [5]. Treatment is aimed at lowering blood glucose to or near normal levels in all patients, hence the use of hypoglycaemic agents/ drugs for its treatment.

In the human body, several chemical reactions are known to take place; these metabolic processes are needed for life [6]. Oxidative reactions are one of such reactions that occur in the human body, and these are known to produce free radicals, that usually are involved in chains of reactions which may damage the cells of the body [6]. These chemical reactions are also part of the normal chemical processes in the body and are known to build up (referred often as oxidative stress) as the person ages, and are connected to certain diseases such as diabetes, cancer, autoimmune and inflammatory reactions [6]. This natural process of oxidative stress can accelerate due to exposure to toxic chemicals such as pesticides, air pollution, smoking, alcohol and fried foods and are regressed by antioxidants such as Vitamins $\mathrm{C}$ and $\mathrm{E}$, glutathione, beta-carotene, and plant estrogens called phytoestrogens [7]. Antioxidants have been isolated in several plants (vegetables, fruits, nuts and other parts) [8].

Medicinal herbs have consistently been considered the leading source of therapeutic entities, employed in the treatment of various human diseases due to their high chemical diversity and broad biological functionality [9]. Several indigenous medicinal plants are employed in the traditional management of several kinds of diseases but there is a need to conduct pharmacological studies to ascertain their therapeutic values. Some reported plants with antidiabetic potentials are Allium sativum L (garlic), Psidium guajava L (guava), Vigna sinensis (cow bean) and Solanum nigrum L. (black nightshade) [9]. Pharmacological and toxicological evaluations of potential medicinal plants are pertinent to drug discovery. The scientific scrutiny of potential medicinal plants is highly recommended [10].
Andira inermis is highly recommended among herbal practitioners in Federal Capital Territory, Nigeria, and purported to have a soothing effect for the generally ill, and thought to help diabetes mellitus sufferers. Andira inermis is a tall evergreen tree with a luxuriant, spreading canopy of large, glossy, rich green leaves and attractively scented small flowers [11], bark fissured and scaly, with an unpleasant cabbage-like smell. The trunk frequently forms buttresses up to 3 $\mathrm{m}$ tall. The leaves alternate, imparipinnate, $15-40 \mathrm{~cm}$ long, with 7-17 leaflets, bright tan when young and shiny green when mature [12]. A decoction of the leaves is used as beverage (leaf decoction also used for washing in Africa), the fruits are eaten, the bark is used as a vermifuge, narcotic and purgative [11], the inner bark is used to treat snake bites [11] and the seeds have purgative and narcotic properties [12] and are also toxic [11]. The stem bark of Andira inermis is the part of interest used in this study.

In a pharmacognostic study, it is necessary to test the safety profile of the extract of interest, before engaging in authentication studies that would test the folkloric claims. It is noteworthy that plants may have injurious elements as part of their natural constituents (phytochemicals) or acquired during their preparation [13]. There have been renal and hepatic failure reports following the consumption of herbal products [14]. Researchers are round the clock in extensive research to find alternative therapies to the already existing ones which are not devoid of adverse effects [15]. The primary goal of the researchers in this study was to screen Andira inermis for its antidiabetic and antioxidant potentials.

\section{Materials and methods}

\section{Plant collection and preparation}

Andira inermis stem bark was collected from Suleja, Niger State in December, 2017. It was identified by Malam I. Muazzam, a plant taxonomist with the Ethnobotany and Herbarium section of the National Institute for Pharmaceutical Research and Development (NIPRD) Abuja, Nigeria. It was then deposited in the herbarium of the Institution (NIPRD) with a herbarium number NIPRD.H.7073.

The plant material was air-dried and pulverized; two kilogrammes $(2 \mathrm{~kg})$ of the powder was collected, double macerated and extracted with $5 \mathrm{l}$ of $80 \%$ methanol following agitation on a shaker for $24 \mathrm{~h}$. The extract dissolved in the solvent was then concentrated in a rotary evaporator. The yield was then calculated after the extracted concentrate was weighed. The yield was calculated using the extracted concentrate weight (as the practical yield) in the given formula: 


\section{Animals}

Albino Rats of both sexes obtained from NIPRD were used for the study. The rats were housed in metal cages in the experimental house of the Faculty of Veterinary Medicine, University of Abuja, Nigeria and were allowed to acclimatize for 2 weeks before the commencement of the experiment. They were maintained at room temperature $\left(37^{\circ} \mathrm{C}\right) ; 12 \mathrm{~h} / 12 \mathrm{~h}$ light/dark cycle, allowed free access to standard rat feeds and water, for 2 weeks before experimentation. Twelve hours before commencement of experiment, feed was withdrawn but water made available ad libitum.

\section{Chemicals, reagents and drugs}

Methanol, Ascobic acid, 1,1-Diphenyl-2-Picrylhydrazyl Radical (DPPH), ferric tripyridyltriazine (Fe (III)-TPTZ) from Sigma Aldrich, Germany. Glibenclamide, distilled water, olive oil, Accu-Chek active stripes, mentholated spirit, cotton wool, $5 \mathrm{ml}, 10 \mathrm{ml}$ syringes, surgical blade, and disposable gloves were used in the experiments.

\section{Phytochemical analysis}

The phytochemical tests on the methanolic extract of $A$. inermis were conducted using standard methods [16]. The extract of $A$. inermis was analysed for saponins, terpenes, tannins, steroids, flavanoids, anthraquinones, carbohydrates and alkaloids.

\section{Antioxidant activity \\ Ferric reducing antioxidant power (FRAP)}

Ferric reducing ability of plant extract, a simple test of total antioxidant power, depends upon the reduction of ferric tripyridyltriazine (Fe (III)-TPTZ) complex to ferrous tripyridyltriazine (Fe (II)-TPTZ) at low $\mathrm{pH}$. The test was carried out as described by Benzie and Strain [17]. Fe (II)-TPTZ with an intense blue colour was monitored at $593 \mathrm{~nm}$. This automated method for measuring FRAP was as modified [18] in a manual assay, carried out in the following steps:

Firstly, Acetate buffer $300 \mathrm{mmol} / \mathrm{pH} 3.6$ (3.1 g sodium acetate $\times 3 \mathrm{H}_{2} \mathrm{O}$ and $16 \mathrm{ml}$ concentrated acetic acid per liter of buffer solution) is constituted. Then $10 \mathrm{mmol} / \mathrm{L}$ of 2,4,6-tripyridyl-8-triazine (TPTZ) in $40 \mathrm{mmol} / \mathrm{L} \mathrm{HCl}$ is made. And this is followed by constituting $20 \mathrm{mmol} / \mathrm{L}$ of $\mathrm{FeCl}_{3} \times 6 \mathrm{H}_{2} \mathrm{O}$ in distilled water.

FRAP working solution: $25 \mathrm{ml}$ acetate buffer, $2.5 \mathrm{ml} \mathrm{TPTZ}$ solution and $2.5 \mathrm{ml} \mathrm{FeCl}_{3} \times 6 \mathrm{H}_{2} \mathrm{O}$ solutions is prepared.

The Sample- FRAP reagent $2 \mathrm{ml}$ and extract $100 \mu \mathrm{l}$ monitored for $5 \mathrm{~min}$ at $593 \mathrm{~nm}, 1 \mathrm{~cm}$ light path and $25^{\circ} \mathrm{C}$. The antioxidant activity of the extract $(25-400 \mu \mathrm{g} /$ $\mathrm{mL}$ ) was compared with that of ascorbic acid as a standard. Calculated as FRAP value of sample $(\mu \mathrm{M})$ :

\section{1, 1-Diphenyl-2-Picrylhydrazyl radical (DPPH) assay}

The free radical scavenging capacity of the aqueous methanolic extract of $A$. inermis stem bark was determined and compared to that of a standard (ascorbic acid) as described in a standard method [19]. $2 \mathrm{ml}$ of the extract at varying concentrations ranging from 25 to $400 \mu \mathrm{g} / \mathrm{mL}$ was mixed with $1 \mathrm{ml}$ of $0.5 \mathrm{mM} \mathrm{DPPH}$ (in methanol) in a cuvette. The absorbance (Abs) at $517 \mathrm{~nm}$ was taken after 30 min of incubation in the dark at room temperature. The experiment was carried out in triplicate. The percentage antioxidant activity was calculated as follows:

Antioxidant activity $=100-\left[\left\{\mathrm{Abs}_{\text {sample }}-\mathrm{Abs}_{\text {blank }} \mathrm{x} 100\right\} / \mathrm{Abs}_{\mathrm{control}}\right]$.

A mixture of $1.0 \mathrm{ml}$ of methanol plus $2.0 \mathrm{ml}$ of the extract was used as the blank while $1.0 \mathrm{ml}$ of the $0.5 \mathrm{mM}$ DPPH solution plus $2.0 \mathrm{ml}$ of methanol was used as the negative control while ascorbic acid was used as a standard reference.

\section{Acute toxicity study}

The method described by Lorke [20] was used. The animals (rats) were treated with aqueous methanolic extract of Andira inermis stem bark. The first phase of the experiment engaged nine rats of both sexes ( 6 males; 3 females) which were separated into 3 groups of 3 rats each (2males and a female) treated orally with 10, 100 and $1000 \mathrm{mg} / \mathrm{kg}$ of the extract, respectively. The animals were observed two (2) hourly for 3 days and the toxic effects exhibited were noted. In the absence of mortality, new sets of rats were treated in the same manner at 2000, 3000 and $5000 \mathrm{mg} / \mathrm{kg}$ respectively. The surviving animals were monitored for 14 days. The oral median lethal dose were calculated using the formula: LD50 = $\sqrt{ }($ Minimum toxic dose $\times$ maximum toxic dose $)[21]$.

\section{Normoglycaemic study}

Normal rats were used to determine the anti hyperglycaemic prophylactic activity of the aqueous methanolic extract of $A$. inermis stem bark. In this study, there were 5 groups (i, ii, iii, iv and v). Group i consists of normal rats treated with distilled water $(20 \mathrm{ml} / \mathrm{kg})$ to serve as the negative contol. The rats in group ii were treated with glibenclamide $(0.2 \mathrm{mg} / \mathrm{kg}$ p.o $)$ to serve as the reference hypoglycaemic drug while the rats in groups iii, iv,and v received the extract at the doses of 100, 200 and $400 \mathrm{mg} / \mathrm{kg}$ per os respectively. Blood glucose levels were then measured prior to, $0.5,1,2$, and $4 \mathrm{~h}$ after administration. Blood glucose levels were compared with those of the control group. Blood glucose levels were measured in $\mathrm{mg} / \mathrm{dl}$ with a glucometer, using tail tipping blood sample technique [22].

Change in absorbance of standard $(0-5 \mathrm{~min}) \mathrm{X}$ FRAP value of standard $(1000 \mu \mathrm{M})$

Change in absorbance of standard $(0-5 \mathrm{~min})$ 
The group constitution and experimental procedure are keeping to a standard [23]. Results were also presented as calculated percentage decrease of the initial value [23].

\section{Glucose challenge test}

In this study, the glucose challenge test (Oral Glucose Tolerance Test (OGTT)) a standard experimental procedure was followed [23]. The experiment constituted of 5 groups (i, ii, iii, iv and v). Group i consists of normal rats treated with distilled water $(20 \mathrm{ml} / \mathrm{kg})$ to serve as the negative control while the rats in group ii were treated with glibenclamide $(0.2 \mathrm{mg} / \mathrm{kg}$ p.o $)$ to serve as the reference hypoglycaemic drug. The rats in groups' iii, iv and $v$ received the extract at the doses of 100, 200 and $400 \mathrm{mg} / \mathrm{kg}$ per os respectively. Prior to experimentation, at zero hour, blood glucose was taken. Hyperglycemia was induced by oral administration of glucose (10 $\mathrm{g} / \mathrm{kg}$,) to the 5 rats in each group. Thirty minutes before the administration of glucose, the animals ( 5 per group) were treated with a single oral administration of the extract $(100,200$, and $400 \mathrm{mg} / \mathrm{kg}$ ) (extract treatment groups), distilled water $(20 \mathrm{ml} / \mathrm{kg}$ ) (negative control group) and glibenclamide $(0.2 \mathrm{mg} / \mathrm{kg}$ ) (positive control group). Blood glucose levels were determined for $3 \mathrm{~h}$, at $1 \mathrm{~h}$ intervals, and $30 \mathrm{~min}$ after glucose administration. The blood glucose levels were compared with the negative control group and a positive control. Blood glucose was measured with the glucometer $(\mathrm{mg} / \mathrm{dl})$ using tail tipping blood sample technique [22].

\section{Statistical analysis}

The SPSS statistical software (version 20) was employed for the analysis. Results were expressed as Mean \pm SEM. Data were analysed using one-way analysis of variance (ANOVA) while Tukey test was used for the post hoc analyses. Significance level was set at $p \leq 0.05$.

\section{Results}

\section{Extract yield}

The aqueous methanolic extract of $A$. inermis stem bark was brown, slurry, oily compound with a percentage yield of $12.3 \%$.

\section{Phytochemical analyses}

The aqueous methanolic extract of Andira inermis stem bark was found to contain saponins, terpenes, tannins, steroids, flavonoids, carbohydrates and alkaloids (Table 1).

\section{Anti oxidant activity}

FRAP test

In the multiple comparisons between concentrations, $A$. inermis $25 \mu \mathrm{g} / \mathrm{ml}$ was found not to be significantly different with $50 \mu \mathrm{g} / \mathrm{ml}$ concentration group. But all other concentrations were found to be significantly different
Table 1 Phytochemical constituents of aqueous methanolic extract of Andira inermis stem bark

\begin{tabular}{lc}
\hline Phytochemical & Inference \\
\hline Saponins & ++ \\
Terpenes & + \\
Tannins & + \\
Steroids & + \\
Flavonoids & - \\
Anthraquinones & + \\
Carbohydrates & + \\
Alkaloids & \\
\hline $\begin{array}{l}\text { Key } \\
+ \text { Present in trace quantity, }++ \text { Present in moderate }\end{array}$ \\
concentration, +++ Present in high concentration - Abscence
\end{tabular}

$(p \leq 0.05)$ with the other concentrations. With regards to ascorbic acid the different concentrations were significantly $(p \leq 0.05)$ different between concentrations. ANOVA between groups were significant in both $A$. inermis and the standard ascorbic acid. The antioxidant activity (FRAP Test) of A.inermis is presented in comparison with Ascorbic acid a standard antioxidant in Fig. 1.

\section{DPPH test}

In the multiple comparisons between concentrations, $A$. inermis $25 \mu \mathrm{g} / \mathrm{ml}$ was found not to be significantly different with the $50 \mu \mathrm{g} / \mathrm{ml}$ and $100 \mu \mathrm{g} / \mathrm{ml}$ concentration group but significant with the $200 \mu \mathrm{g} / \mathrm{ml}$ and $400 \mu \mathrm{g} / \mathrm{ml}$ concentrations $(p \leq 0.05)$. And for the Ascorbic acid, the different concentrations were significantly $(p \leq 0.05)$ different between concentrations (with exception of these paired concentrations 100 by 200 or the $400 ; 200$ by 100 or 400 and 400 by 100 or 200). In matching the concentrations between the standard antioxidant and the extract, the ascorbic acid groups showed a greater percentage of activity than all the groups of the A. inermis. But the 200 and $400 \mu \mathrm{g} / \mathrm{mL}$ of the $A$. inermis $(71.040 \%, 72.400 \%)$ could match the percentage activity of the $25 \mu \mathrm{g} / \mathrm{mL}$ of the ascorbic acid standard (70.773\%) (Fig. 2).

\section{Acute toxicity}

The animals presented with a transient dullness that lasted for about $20 \mathrm{~min}$ post treatment. There were no deaths recorded following the single dose administration of the extract orally (Table 2). The $\mathrm{LD}_{50}$ of the extract was estimated to be therefore greater than $5000 \mathrm{mg} / \mathrm{kg}$.

\section{Normoglycaemic test result}

In this study there was no significance in the $0 \mathrm{~h}, 1 / 2 \mathrm{~h}$, $1 \mathrm{~h}, 3 \mathrm{~h}$ and $4 \mathrm{~h}$ but there was significant difference at 2 $\mathrm{h}$ mark in all the groups (Table 3 ). The calculated blood glucose difference and the percentage reduction in blood glucose showed the relative control of the blood glucose, 


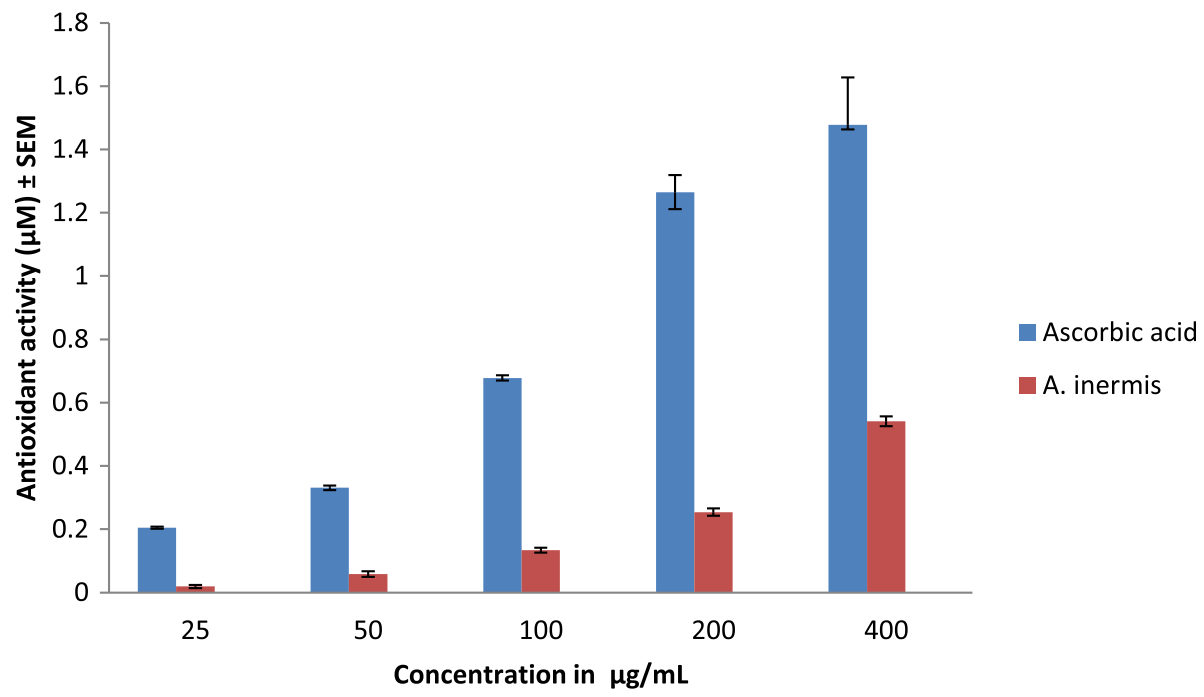

Fig. 1 FRAP Test showing A.inermis antioxidant activity (red bars) with Ascorbic acid (blue bars) as standard comparison

clearly indicating the positive glucose difference and the positive percentage reduction in blood glucose from the 2nd hour to the 4th hour in the extract treatment group (Table 4).

\section{Glucose challenge test}

In this study (Oral Glucose Tolerance Test (OGTT)) there was significance difference in the $0 \mathrm{~h}, 1 / 2 \mathrm{~h}, 1 \mathrm{~h}, 2 \mathrm{~h}, 3 \mathrm{~h}$ and $4 \mathrm{~h}$ in all the groups (Table 5). There was a significant difference noticed at the zero hour (Table 5). This deficiency (significant difference noticed at the zero hour) can be overcome / undermined if the blood glucose difference and percentage reduction of blood glucose are calculated and compared (Table 6). The calculated blood glucose difference and the percentage reduction in blood glucose showed the relative handling of the blood glucose by the treatment groups to the controls.

\section{Discussion}

The phytochemicals present in the plant: saponins,terpenes, tannins, steroids, flavanoids, carbohydrates and alkaloids show the richness of the plant in phytochemicals which may have bioactive properties [24]. And it has been reported that the common phytoconstituents found in medicinal plants with antidiabetic potential include polyphenols, flavonoids, terpenoids, tannins, alkaloids, saponins [25], some of which are present (terpenes, tannins, flavanoids, and alkaloids) in $A$. inermis.

The blanket recommendation (soothing effect for the generally ill) by most herbalists brought about the inclusion

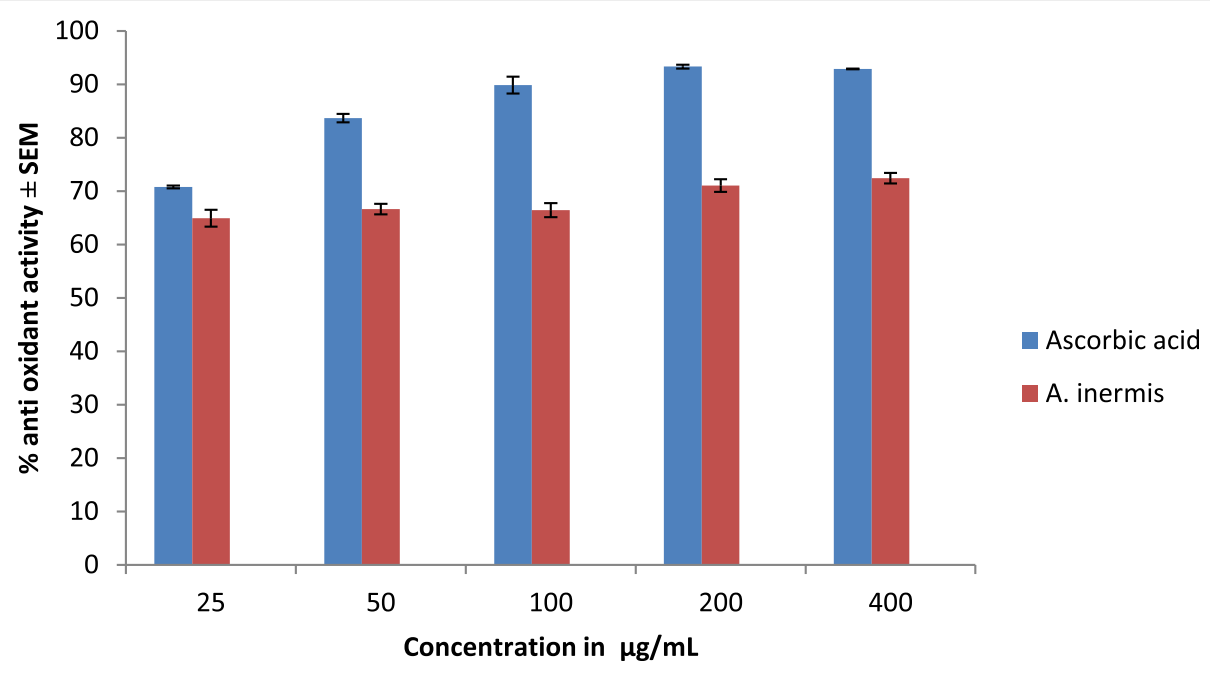

Fig. 2 DPPH Test showing A.inermis percentage antioxidant activity (red bars) with Ascorbic acid as standard comparison (blue bars) 
Table 2 Acute toxicity study of aqueous methanolic extract of A. inermis showing death recorded

\begin{tabular}{llll}
\hline $\begin{array}{l}\text { Dose } \\
\mathbf{m g} / \mathbf{k g}\end{array}$ & Group 1 & Group 2 & Group 3 \\
\hline Phase I & & & \\
10 & $0 / 3$ & $0 / 3$ & $0 / 3$ \\
100 & $0 / 3$ & $0 / 3$ & $0 / 3$ \\
1000 & $0 / 3$ & $0 / 3$ & $0 / 3$ \\
Phase II & & & \\
2000 & $0 / 3$ & $0 / 3$ & $0 / 3$ \\
3000 & $0 / 3$ & $0 / 3$ & $0 / 3$ \\
5000 & $0 / 3$ & $0 / 3$ & $0 / 3$ \\
\hline
\end{tabular}

Key

$0 / 3=$ Number of animals which died/number of animals used

of the antioxidant study employed in this research. This seem to be true because of the findings in both tests (FRAP and DPPH) employed for the evaluation of the antioxidant effects of this plant extract in vitro. In a scale of 100, a $72.4 \%$ antioxidant activity is good for the $400 \mu \mathrm{g} / \mathrm{mL}$ of the $A$. inermis treatment group, though the best activity was recorded for the standard, ascorbic acid (93.333\%) at $200 \mu \mathrm{g} /$ $\mathrm{mL}$. Indeed researchers have found present in various plants antioxidants. Screening of some Nigerian medicinal plants for antioxidant activity [26] using 2, 2, diphenylpicryl-hydrazyl radical revealed all twenty- two plants to have varying percentages/degrees of antioxidant activity; Alstonia bonei, cortex, Alstonia bonei, folium, Alstonia bonei, radix, Byrsocarpus coccineus, folium, Cnestis ferruginea, folium, Funtumia elastical, Landolfia owariensis, folium to mention a few. Also reported are the presence of natural antioxidants widely distributed in food (papaya, carrot, olive kernel, orange, prickly pear beverages) and medicinal plants [27]. A. inermis has flavaniods as part of its phytochemicals known to possess antioxidant properties [28]. It is true that free radicals are known to build up in the body and have been associated with many disease states due to more free radicals present than can be kept in balance. Antioxidants are known to repress the buildup of these free radicals, or keep them in balance, thereby improving health [29].

The acute toxicity study showed the methanolic extract of A. inermis to be safe having an $\mathrm{LD}_{50}$ of greater than 5000 $\mathrm{mg} / \mathrm{kg}$. This level is considered of a test compound as being practically non- toxic on an acute exposure [30]. There are reports of medicinal plants extract with even higher acute safety profiles, Cassia fistula L. (Caesalpiniaceae) and Hippophae rhamniodes (Elaeagnaceae), both plants were found to be safe up to the dose of $10,000 \mathrm{mg} / \mathrm{kg}$ [31]. It is a safe practice to embark on an acute toxicity study as a prelude to further pharmacological assessment of a test compound, especially in the animal to be tested for more study. It is known that, there are injurious elements present or naturally occurring as constituents or acquired during the preparation of test substances [13] making this pharmacological activity (acute toxicity study) worthy of practice.

The use of normal healthy animals is still a valid screening method for testing potential oral hypoglycaemic agents [32]. The hypoglycaemic activity of $A$. inermis extract in normal rats showed the extract to significantly $(P \leq 0.05)$ reduce normal rats' blood glucose level at the 2 nd hour post treatment which was also significant in the glibenclamide treatment group. The blood glucose difference and percentage reduction in blood glucose (Table 4) helped to further elucidate the significance, showing the control group to have $-5.6(-8.7 \%)$ poor glucose handling; and the glibenclamide /extract treatment group $(100 \mathrm{mg} / \mathrm{kg})$ to positively reduce blood glucose $14.8(26.8 \%) \& 16.4(25.9 \%)$ respectively. This is a positive finding that the extract has a potential to be an oral hypoglycaemic agent.

The potential of the methanolic extract of $A$. inermis as a hypoglycaemic agent was more obvious in the Glucose challenge test (Oral glucose loading animal model - Oral Glucose Tolerance Test (OGTT)) (Table 5), often referred to as physiological induction of diabetes mellitus because

Table 3 Hypoglycaemic activity of $A$. inermis extract in normal rats

\begin{tabular}{|c|c|c|c|c|c|c|}
\hline Blood sugar in $\mathrm{mg} / \mathrm{dl}$ & Control & $\begin{array}{l}\text { Gliben- clamide } \\
\text { Treatment Group }\end{array}$ & $100 \mathrm{mg} / \mathrm{kg}$ & $200 \mathrm{mg} / \mathrm{kg}$ & $400 \mathrm{mg} / \mathrm{kg}$ & $\begin{array}{l}\text { Anova Sig. } \\
\text { Diff. Bw grps }\end{array}$ \\
\hline $\mathrm{Oh}$ & $\begin{array}{l}64.200 \\
\pm 6.771\end{array}$ & $\begin{array}{l}55.200 \\
\pm 0.917\end{array}$ & $\begin{array}{l}63.200 \\
\pm 6.304\end{array}$ & $\begin{array}{l}58.400 \\
\pm 2.462\end{array}$ & $\begin{array}{l}63.000 \\
\pm 2.213\end{array}$ & 0.351 \\
\hline $1 / 2 \mathrm{hrs}$ & $\begin{array}{l}76.200 \\
\pm 6.538\end{array}$ & $\begin{array}{l}80.000 \\
\pm 4.680\end{array}$ & $\begin{array}{l}86.600 \\
\pm 6.517\end{array}$ & $\begin{array}{l}89.800 \\
\pm 3.513\end{array}$ & $\begin{array}{l}82.400 \\
\pm 2.205\end{array}$ & 0.860 \\
\hline $1 \mathrm{~h}$ & $\begin{array}{l}72.400 \\
\pm 9.600\end{array}$ & $\begin{array}{l}79.000 \\
\pm 4.050\end{array}$ & $\begin{array}{l}70.200 \\
\pm 5.490\end{array}$ & $\begin{array}{l}82.800 \\
\pm 5.490\end{array}$ & $\begin{array}{l}70.400 \\
\pm 2.702\end{array}$ & 0.600 \\
\hline $2 \mathrm{~h}$ & $\begin{array}{l}* 69.800 \\
\pm 5.508\end{array}$ & $\begin{array}{l}* 40.400 \\
\pm 1.778\end{array}$ & $\begin{array}{l}* 46.800 \\
\pm 1.463\end{array}$ & $\begin{array}{l}* 54.400 \\
\pm 2.942\end{array}$ & $\begin{array}{l}* 66.000 \\
\pm 2.302\end{array}$ & 0.000 \\
\hline $3 \mathrm{~h}$ & $\begin{array}{l}65.800 \\
\pm 4.747\end{array}$ & $\begin{array}{l}58.000 \\
\pm 3.066\end{array}$ & $\begin{array}{l}58.600 \\
\pm 5.335\end{array}$ & $\begin{array}{l}58.400 \\
\pm 4.130\end{array}$ & $\begin{array}{l}56.000 \\
\pm 1.581\end{array}$ & 0.734 \\
\hline $4 \mathrm{~h}$ & $\begin{array}{l}57.400 \\
\pm 8.078\end{array}$ & $\begin{array}{l}49.200 \\
\pm 3.121\end{array}$ & $\begin{array}{l}61.200 \\
\pm 2.518\end{array}$ & $\begin{array}{l}54.800 \\
\pm 5.696\end{array}$ & $\begin{array}{l}52.600 \\
\pm 2.786\end{array}$ & 0.487 \\
\hline
\end{tabular}

$N=5$ values $=\mathrm{mg} / \mathrm{dl}=$ Mean \pm Standard Error of Mean ${ }^{*} P \leq 0.05$ 
Table 4 A.inermis normal rat's blood glucose difference \& Percentage reduction in blood glucose

\begin{tabular}{|c|c|c|c|c|c|}
\hline Blood sugar in $\mathrm{mg} / \mathrm{dl}$ & Control & $\begin{array}{l}\text { Glibenclamide } \\
\text { Treatment } \\
\text { Group }\end{array}$ & $100 \mathrm{mg} / \mathrm{kg}$ & $200 \mathrm{mg} / \mathrm{kg}$ & $400 \mathrm{mg} / \mathrm{kg}$ \\
\hline $1 / 2 \mathrm{hrs}$ & $\begin{array}{l}-12.0 \\
(-18.75 \%)\end{array}$ & $\begin{array}{l}-24.8 \\
(-44.9 \%)\end{array}$ & $\begin{array}{l}-23.4 \\
(-37.0 \%)\end{array}$ & $\begin{array}{l}-31.4 \\
(-53.8 \%)\end{array}$ & $\begin{array}{l}-19.4 \\
(-30.8 \%)\end{array}$ \\
\hline $1 \mathrm{~h}$ & $\begin{array}{l}-8.2 \\
(-12.8 \%)\end{array}$ & $\begin{array}{l}-23.8 \\
(-43.1 \%)\end{array}$ & $\begin{array}{l}-7.0 \\
(-11.1 \%)\end{array}$ & $\begin{array}{l}-24.4 \\
(-41.8 \%)\end{array}$ & $\begin{array}{l}-7.4 \\
(11.7 \%)\end{array}$ \\
\hline $2 \mathrm{~h}$ & $\begin{array}{l}-5.6 \\
(-8.7 \%)^{*}\end{array}$ & $\begin{array}{l}14.8 \\
(26.8 \%)^{*}\end{array}$ & $\begin{array}{l}16.4 \\
(25.9 \%)^{*}\end{array}$ & $\begin{array}{l}4.0 \\
(6.8 \%)^{*}\end{array}$ & $\begin{array}{l}-3.0 \\
(-4.8 \%)^{*}\end{array}$ \\
\hline $3 \mathrm{~h}$ & $\begin{array}{l}-1.6 \\
(-2.4 \%)\end{array}$ & $\begin{array}{l}-2.8 \\
(-5.1 \%)\end{array}$ & $\begin{array}{l}4.6 \\
(7.3 \%)\end{array}$ & $\begin{array}{l}0.0 \\
(0 \%)\end{array}$ & $\begin{array}{l}7.0 \\
(11.1 \%)\end{array}$ \\
\hline $4 \mathrm{~h}$ & $\begin{array}{l}6.8 \\
(10.6 \%)\end{array}$ & $6(10.9 \%)$ & $\begin{array}{l}2.0 \\
(3.2 \%)\end{array}$ & $\begin{array}{l}3.6 \\
(6.2 \%)\end{array}$ & $\begin{array}{l}10.4 \\
(16.5 \%)\end{array}$ \\
\hline
\end{tabular}

*indicates significant blood glucose difference and percentage reduction

the blood glucose level of the animal is transiently increased with no damage to the pancreas [32]. Here the extract and the glibenclamide treatment groups were seen to have significantly affected the handling of the hyperglycaemia caused by the high loading of the experimental animals with glucose while the vehicle (distilled water) treated group showed a significant poor control / handling of the induced hyperglycaemia. Though there was the challenge in the experimental result (that is, use of rats with a wide range of basic glycaemic levels especially with the control and the glibenclamide treatment groups) which must have accounted for the significant difference noticed at the zero hour. This deficiency was overcome /undermined on calculation of the blood glucose difference and percentage reduction of blood glucose (Table 6) over time. It is clearly seen from the 1st hour up to the 4th hour, that the A.inermis methanolic extract had a better handling of the hyperglycaemic state induced. In the 1st hour (that is $30 \mathrm{~min}$ post ingestion of the glucose and $1 \mathrm{~h}$ post extract treatment) the result showed $-57.4(-$ 89.4\%),-26.8(-33.8\%),-23.8(-26.3\%), - 12.8(-13.9\%) and 9.8(-10.4\%) for the vehicle control, glibenclamide, and the $100,200 \& 400 \mathrm{mg} / \mathrm{kg}$ treatment groups respectively. It is obvious there is a better control of hyperglycaemia with the A. inermis extract treatment groups having a dose dependent effect (towards positivity than even the glabenclamide treatment group). It is even better/clearer at the 3rd hour where the difference in blood glucose and percentage reduction in blood glucose showed deductively, -27.6(-43\%), 5.6(7.1\%), 11.2 (12.4\%), 11.8 (12.9\%) and 4.8 (5.1\%) from the vehicle control group to the $400 \mathrm{mg} / \mathrm{kg}$ extract group respectively. Though at the 4th (last) hour (also listed respectively), the glibenclamide group (in italics and bold) was superior 29.4(-45.8\%), 18.4(23.2\%), 10.2(11.3\%), 9.2(10.0\%) and $4.8(5.1 \%)$ to the vehicle control group that was still in negative (poorest hyperglycaemic control). In a similar study, there was evaluation of the antihyperglycemic effect of Garcinia pedunculata extracts in normal rats following an oral glucose tolerance test (OGTT) that exhibited a dose-dependent significant effect on the glycemic status of rats (ameliorate hyperglycemia). Furtherance to this, the same researchers used diabetic rats and reported that administration of Garcinia pedunculata extract reduced blood glucose levels significantly [33]. It has been reported that phytochemicals such as flavaniods (present in A. inermis), caroteniods and polyphenols possess antioxidant properties that act as

Table 5 Oral Glucose Tolerance Test (OGTT) in rats treated with A. inermis Extract

\begin{tabular}{|c|c|c|c|c|c|c|}
\hline Blood sugar in $\mathrm{mg} / \mathrm{dl}$ & Control & $\begin{array}{l}\text { Glibenclamide } \\
\text { Treatment } \\
\text { Group }\end{array}$ & 100 mg/kg & 200 mg/kg & $400 \mathrm{mg} / \mathrm{kg}$ & $\begin{array}{l}\text { Anova Sig. } \\
\text { Diff. Bw grps }\end{array}$ \\
\hline $\mathrm{Oh}$ & $\begin{array}{l}64.200 \\
\pm 6.468\end{array}$ & $\begin{array}{l}79.200 \\
\pm 5.580\end{array}$ & $\begin{array}{l}90.600 \\
\pm 6.005\end{array}$ & $\begin{array}{l}91.800 \\
\pm 3.007\end{array}$ & $\begin{array}{l}94.200 \\
\pm 7.857\end{array}$ & 0.014 \\
\hline $1 \mathrm{~h}$ & $\begin{array}{l}121.600 \\
\pm 2.943\end{array}$ & $\begin{array}{l}106.000 \\
\pm 3.886\end{array}$ & $\begin{array}{l}114.400 \\
\pm 4.389\end{array}$ & $\begin{array}{l}104.600 \\
\pm 4.578\end{array}$ & $\begin{array}{l}104.000 \\
\pm 10.075\end{array}$ & 0.030 \\
\hline $2 \mathrm{~h}$ & $\begin{array}{l}98.200 \\
\pm 2.498\end{array}$ & $\begin{array}{l}86.400 \\
\pm 2.839\end{array}$ & $\begin{array}{l}84.800 \\
\pm 4.769\end{array}$ & $\begin{array}{l}94.200 \\
\pm 5.860\end{array}$ & $\begin{array}{l}97.200 \\
\pm 5.132\end{array}$ & 0.003 \\
\hline $3 \mathrm{~h}$ & $\begin{array}{l}91.800 \\
\pm 4.893\end{array}$ & $\begin{array}{l}73.600 \\
\pm 3.516\end{array}$ & $\begin{array}{l}79.400 \\
\pm 2.293\end{array}$ & $\begin{array}{l}80.000 \\
\pm 2.323\end{array}$ & $\begin{array}{l}89.400 \\
\pm 3.919\end{array}$ & 0.000 \\
\hline $4 \mathrm{~h}$ & $\begin{array}{l}93.600 \\
\pm 6.022\end{array}$ & $\begin{array}{l}60.800 \\
\pm 4.651\end{array}$ & $\begin{array}{l}80.400 \\
\pm 2.926\end{array}$ & $\begin{array}{l}82.600 \\
\pm 4.822\end{array}$ & $\begin{array}{l}89.400 \\
\pm 4.523\end{array}$ & 0.000 \\
\hline
\end{tabular}

$\mathrm{N}=5$ values $=\mathrm{mg} / \mathrm{dl}=$ Mean \pm Standard error of mean $P \leq 0.05$ 
Table 6 Blood Glucose Difference \& Percentage reduction in Glucose challenge test (OGTT) In rats treated with A. inermis Extract

\begin{tabular}{|c|c|c|c|c|c|}
\hline Blood glucose in $\mathrm{mg} / \mathrm{dl}$ & Control & $\begin{array}{l}\text { Glibenclamide } \\
\text { Treatment } \\
\text { Group }\end{array}$ & $100 \mathrm{mg} / \mathrm{kg}$ & $200 \mathrm{mg} / \mathrm{kg}$ & $400 \mathrm{mg} / \mathrm{kg}$ \\
\hline $\mathrm{Oh}$ & $0 \%$ & $0 \%$ & $0 \%$ & $0 \%$ & $0 \%$ \\
\hline $1 \mathrm{~h}$ & $\begin{array}{l}-57.4 \\
(-89.4 \%)\end{array}$ & $\begin{array}{l}-26.8 \\
(-33.8 \%)\end{array}$ & $\begin{array}{l}-23.8 \\
(-26.3 \%)\end{array}$ & $\begin{array}{l}-12.8 \\
(-13.9 \%)\end{array}$ & $\begin{array}{l}-9.8 \\
(-10.4 \%)\end{array}$ \\
\hline $2 \mathrm{~h}$ & $\begin{array}{l}-34.0 \\
(-53 \%)\end{array}$ & $\begin{array}{l}-7.2 \\
(9.1 \%)\end{array}$ & $\begin{array}{l}5.8 \\
(6.4 \%)\end{array}$ & $\begin{array}{l}-2.4 \\
(-2.6 \%)\end{array}$ & $\begin{array}{l}-3.0 \\
(-3.2 \%)\end{array}$ \\
\hline $3 \mathrm{~h}$ & $\begin{array}{l}-27.6 \\
(-43 \%)\end{array}$ & $5.6(7.1 \%)$ & $\begin{array}{l}11.2 \\
(12.4 \%)\end{array}$ & $\begin{array}{l}11.8 \\
(12.9 \%)\end{array}$ & $\begin{array}{l}4.8 \\
(5.1 \%)\end{array}$ \\
\hline $4 \mathrm{~h}$ & $\begin{array}{l}-29.4 \\
(-45.8 \%)\end{array}$ & $\begin{array}{l}18.4 \\
(23.2 \%)\end{array}$ & $\begin{array}{l}10.2 \\
(11.3 \%)\end{array}$ & $\begin{array}{l}9.2 \\
(10.0 \%)\end{array}$ & $\begin{array}{l}4.8 \\
(5.1 \%)\end{array}$ \\
\hline
\end{tabular}

anticancer, anti aging, and protective actions for cardiovascular diseases, diabetes mellitus and neurodegenerative diseases [28]. It is noteworthy, that treatment with Garcinia pedunculata fruit extract significantly increased the levels of antioxidant enzymes in all tissues (rats) suppressing oxidative stress [33].

In conclusion, the aqueous methanolic extract of $A$. inermis is a relatively safe herbal extract $\left(\mathrm{LD}_{50}=5000 \mathrm{mg} / \mathrm{kg}\right)$, rich in phytochemicals, possesses good antioxidant activity, with potential anti diabetic effect due to its ability to lower blood glucose levels in normal rats and suppress postprandial rise in blood glucose levels. Further experimental models and test (isolation, characterization and bioactive assays) are on the way to thoroughly investigate this extract for its full anti diabetic potential. And the results also authenticate the folklore use (soothing effect for the generally ill and help of diabetes mellitus sufferers) of the plant.

\section{Abbreviations \\ A. inermis: Andira inermis; FRAP: Ferric Reducing/Antioxidant Power; DPPH: 2,2-diphenyl-1-picrylhydrazyl; LD 50 : Lethal dose 50; DM: Diabetic mellitus; WHO: World Health Organization; NIPRD: National Institute for Pharmaceutical Research and Development; Fe (III)-TPTZ: ferric tripyridyltriazine; TPTZ: 2,4,6-tripyridyl-8-triazine; Abs: Absorbance; ANOVA: One-way analysis of variance}

\section{Acknowledgements}

The authors would like to appreciate the technical staff and animal holding unit of the National Institute for Pharmaceutical Research and Development (NIPRD) Abuja, Nigeria.

\section{Authors' contributions}

The research was carried out in collaborations of all the authors. Every author read and approved the final manuscript.

\section{Funding}

TETFUND (tertiary education trust fund) NATIONAL RESEARCH FUND, NIGERIA.

\section{Availability of data and materials}

All data related to this manuscript are presented within the text.

\section{Ethics approval and consent to participate}

Ethical approval was gotten from the University of Abuja Research Ethics Committee on animal use (assigned number UAECAU/2018/002) and the internationally accepted principles for laboratory animal use and care as contained in the Canadian Council on Animal Care Guidelines were followed.
Consent for publication

Not applicable.

\section{Competing interests}

The authors declare that they have no competing interests.

\section{Author details}

${ }^{1}$ Department of Pharmacology and Therapeutics, College of Health Sciences, University of Abuja, Abuja, Nigeria. ${ }^{2}$ Department of Pharmacology \& Toxicology, Faculty of Veterinary Medicine, University of Abuja, Abuja, Nigeria. ${ }^{3}$ Department of Physiology and Pharmacology, Faculty of Veterinary Medicine, Michael Okpara University of Agriculture, Umudike, Abia State, Nigeria.

Received: 1 June 2020 Accepted: 3 November 2020

Published online: 13 November 2020

\section{References}

1. Ginter E, Simko V. Diabetes type 2 in the $21^{\text {st }}$ century. Bratisl Listu. 2010; 111(3):134-7.

2. World Health Organization (2013). 10 Facts about diabetes. Fact file. www. who.int/features/factfiles/diabetes/en/\# (7/6/2013).

3. King H, Aubert RE, Herman WH. Global burden of diabetes, 1995-2025: prevalence, numerical estimates, and projections. Diabetes Care. 1998;21(9):1414-31.

4. Edwards CRW, Band JD, Frier BM, Shephend JADT. In: Davisons principles and practices of medicine $\left(17^{\text {th }}\right)$. Endocine and metabolic diseases, including diabetes mellitus (chapter 12). ELBS low priced books; 1995.

5. American Diabetes Association [ADA]. Diagnosis and classification of diabetes mellitus. Diabetes Care. 2010;33(1):S62-9.

6. Ahmad R. Introductory chapter: basics of free radicals and antioxidants. Free Radicals, Antioxidants and Diseases, Rizvan Ahmad, IntechOpen, DOI. 2018. https://doi.org/10.5772/intechopen.76689.

7. Villines Z. How do free radicals affect the body? In: Medical news today; 2017. Retrieved from https://www.medicalnewstoday.com/ articles/318652.php.

8. Jagtap UB, Panaskar SN, Bapat VA. Evaluation of Antioxidant Capacity and Phenol Content in Jackfruit (Artocarpus heterophyllus Lam.) Fruit Pulp. Plant Foods Hum Nutr. 2010;65:99-104. https://doi.org/10.1007/ s11130-010-0155-7 Published online: 3 March 2010 \# Springer Science+ Business Media, LLC 2010.

9. Ahmad, M., Khan, M., Arshad, M., Zafar, M. (2004). Ethnophytotherapical approaches for the treatment of diabetes by the local inhabitants of district Attock (Pakistan). Southen Illinois University. Private ed. Available online at http://www.sui.edu/ebl/leaflets/phyto.htm.

10. Nurul Izzati Osman, Norrizah Jaafar Sidik and Asmah Awal. Ethnobotanical Profiles and Phytochemical Constituents of Barringtonia racemosa L. for Potential Scrutiny of Bioactive Compounds through Plant Biotechnology. J Nat Remedies | ISSN: 2320-3358 www.informaticsjournals.com/index.php/ jnr. 2017, 2017;17(2). https://doi.org/10.18311/jnr/2017/15945.

11. Tropical Plants Database, Ken Fern. tropical.theferns.info. 2019-10-08. tropical.theferns.info/viewtropical.php?id=Andira+inermis.

12. Orwa et al.2009 Agroforestry Database 4.0 www.worldagroforestry.org 
13. Keen RW, Deacon AC, Delves HT, Moreton JA, Frost PJ. Indian remedies for diabetes as a cause of lead poisoning. Postgrad Medical Journal. 1994;70:113-4.

14. Calixto JB. Efficacy, safety, quality control, marketing and regulatory guidelines for herbal medicines ( Phytotherapeutic agents). Brazil J Med Boil Res. 2000;33:179-89. https://doi.org/10.1590/s0100-879×2000000200004.

15. Deruiter J. 2003 "Overview of the antidiabetic agents," Endocrine Pharmacotherapy Module; 2003. p. 33.

16. Evans WC. Trease and Evans Pharmacognosy. 15th ed, Saunders, an Imprint of Elsevier. Printed in India; 2005. p. 223-308.

17. Benzie IF, Strain JJ. 1996. The ferric reducing ability of plasma (FRAP) as a measure of "antioxidant power": the FRAP assay. Anal Biochem. 1996;239(1): 70-6. 8660627. https://doi.org/10.1006/abio.1996.0292.

18. Varga ISZ, Matkovics B, Sasvári M, Salgó L. Comparative study of plasma antioxidant status in normal and pathological cases. Curr Topics Biophys. 1998:22(suppl):219-24.

19. Mensor LL, Menezes FS, Leitao GG, Reis AS, dos Santos TC, Coube CS, Leitao SG. Screening of Brazilian plant extracts for antioxidant activity by the use of DPPH free radical method. Phytother Res. 2001;15:127-30.

20. Lorke D. A new approach to practical acute toxicity testing. Arch Toxicol. 1983;54(4):275-87. https://doi.org/10.1007/BF01234480.

21. Abdu Z, Dimas K, Sunday OA, Sunday D, Elisha BB. In vivo Acute Toxicity (LD50) Studies and Phytochemical Screening of Stem Bark Extracts of Detarium microcarpumGuill and per (Caesalpinioideae) and Myosortisscorpioides L.(boraginaceae). Curr Trend Biomed Eng Biosci. 2018; 14(4):555891. https://doi.org/10.19080/CTBEB.2018.14.555891.

22. Diehl K-H, Hull R, Morton D, Pfister R, Smith YRD, Vidal J-M, van de Vorstenbosch C. A Good Practice Guide to the Administration of Substances and Removal of Blood, Including Routes and Volumes. J Appl Toxicol. 2001;21:15-23.

23. Cunha W.R., W.R. Arantes, G.M. Ferreira, D.S. Lucarini, R. Silva, M.L.A. Furtado, N.A.J.C. da Silva Filho, A.A. Crotti, A.E.M. Araujo A.R.B. (2008). "Hypoglycemic effect of Leandra lacunose in normal and alloxan induced diabetic rats". FITOTERAPIA. [Online] Available: www.elsevier.com/locate/fitote.

24. Rui LH. Dietary Bioactive Compounds and Their Health Implications. J Food Sci. 2013;78:SI

25. Yatoo MI, Saxena A, Gopalakrishnan A, Alagawany M, Dhama K. Promising Antidiabetic drugs, medicinal plants and herbs: an update. Int J Pharmacol. 2017;13:732-45. https://doi.org/10.3923/ijp.2017.732.745 URL: https://scialert. net/abstract/?doi=ijp.2017.732.745.

26. Oke JM, M,O. Hamburger. Screening of some Nigerian medicinal plants for antioxidant activity using 2, 2, diphenyl-picryl-hydrazyl radical. Afr J Biomed. Res. 2002:5:77-9.

27. Xu D-P, Li Y, Meng X, Zhou T, Zhou Y, Zheng J, Zhang J-J, Li H-B. Natural antioxidants in foods and medicinal plants: extraction, assessment and resources. Int J Mol Sci. 2017;18:96.L Sci. Published online 2017 Jan 5. https://doi.org/10.3390/ijms18010096.

28. Yu-Jie Z, Gan R-Y, Li S, Zhou Y, Li A-N, Xu D-P, Li H-B. Antioxidant phytochemicals for the prevention and treatment of chronic diseases. Molecules. 2015;20:21138-56. https://doi.org/10.3390/molecules201219753 www.mdpi.com/journal/molecules.

29. Megan Dix 2017 Everything you should know about oxidative stress. Medically reviewed by Timothy J. Legg https://www.sciencedirect.com/ science/article/pii/0278691594900116

30. OECD/OCDE 420: Adopted $17^{\text {th }}$ December 2001. OECD Guideline for Testing of Chemicals. Acute Oral Toxicity - Fixed Dose Procedure iccvam. niehs.nih.gov/SuppDocs/FedDocs/OECD/OECD GL420.pdf..

31. Khan BA, Akhtar N. Phytochemical analysis and acute toxicity tests of two medicinal plant extracts. J Med Plants Res. 2012;6(19):3545-8 Available online at http://www.academicjournals.org/JMPR DOI: 10.5897/JMPR11.1515 ISSN 1996-0875 @2012 Academic Journals.

32. Etuk EU. Animals Models for studying diabetes mellitus. Agric Biol J North America. ISSN Print; 2151-7517,ISSN Online. 2010:2151-7525.

33. Ali MY, Paul S, Tanvir EM, Hossen MS, Rumpa NN, Saha M, Khalil MI. Antihyperglycemic, Antidiabetic, and antioxidant effects of Garcinia pedunculata in rats. Evid Based Complement Alternative Med. 2017;2017: 2979760. https://doi.org/10.1155/2017/2979760.

\section{Publisher's Note}

Springer Nature remains neutral with regard to jurisdictional claims in published maps and institutional affiliations.

\section{Submit your manuscript to a SpringerOpen ${ }^{\circ}$ journal and benefit from:}

- Convenient online submission

- Rigorous peer review

- Open access: articles freely available online

High visibility within the field

- Retaining the copyright to your article

Submit your next manuscript at $\boldsymbol{\nabla}$ springeropen.com 